\title{
How to Innovate Management Accounting for Public Sector: An Italian Case Study
}

\author{
S. Cosimato, C. Torre, O. Troisi \\ University of Salerno, Salerno, Italy
}

\begin{abstract}
In recent years, the general reform of public sector has also interested accounting policies, techniques, and tools in order to make them as clear and understandable as possible. Thus, citizens and private organizations are even more demanding for a new and deeper disclosure of public accounting policies, fundamental to make them properly understood. This seems to be particularly important also because understanding public accounting policies is quite complex, because they highly vary not only among different countries, but also within a single country. It is also to be noted that in modern society, financial issues play a pivotal role in terms of public organizations' efficiencies and competitiveness. This paper aims to investigate the spread and the application of emerging accounting policies and practices designed for public organizations. The analysis of a specific case study, settled in Italian context, points to better understand how public managers perceive the introduction and the results achieved through emerging accounting tools. The analysis offers some interesting insights in terms of new management accounting policies appliance to public organizations, in order to better respond to the emergent need for a much more open and transparent public management.
\end{abstract}

Keywords: post new public management (post-NPM), accounting, public trust

In public sector, the fiscal environment is facing the increasing pressure for a better management, based on specific policies and tools open to public intervention and on a transparent communication. These issues are at the roots of the post new public management (post-NPM), aiming to reform central capacity, control, and coordination between all public sectors through a value-based management (Pollitt \& Bouckaert, 2004; Christensen \& Lægreid, 2007), being mainly focused on horizontal collaboration and on a value-based management (Dong, Christensen, \& Painter, 2009). The post-NPM represents the most recent evolution of public management, which comes after the rethinking of the old public administration (embodied by hierarchal and Weberian forms of bureaucracy), and of the NPM reform, based on disaggregation, autonomization, agencification, and marketization. In the last step of public sector reformation, the post-NPM is mainly focused on the integration between public and private sector and civil society, also thanks to the increasing of central

Corresponding author: S. Cosimato, Ph.D. in marketing and communication, Department of Management and Information Technology, University of Salerno, Italy; research fields: marketing, digital marketing, corporate communication, sustainability, CSR, logistics, business management, and supply chain management. E-mail: scosimato@unisa.it.

C. Torre, Ph.D. candidate in public company management, Department of Management and Information Technology, University of Salerno, Italy; research fields: business administration, business management, and supply chain management. E-mail: ctorre@unisa.it.

O. Troisi, Ph.D. in public company management, Department of Management and Information Technology, University of Salerno, Italy; research fields: business ethics, business administration sustainability, CSR, logistics, business management, and supply chain management. E-mail: otroisi@unisa.it. 
government managerial capacity. A great attention has also been paid to public accounting systems and on those strategies that can contribute to make it stable, transparent, and acceptable.

Starting from 90s, several Western countries have reformed some sectors of public administration, aiming to improve management practices and performance appraisals in order to increase efficiency and make them more responsive than ever. This reform has interested also public accounting systems; thus, for the first time, many governments have focused their attention on the improving or development of better control systems, a better management and decision-making, and a more efficient public resources assignation. To achieve this goal, public institutions have implemented new accounting policies and tools mainly based on digital technologies and contributing to administrative processes digitalization. This general reformation points also to make public organizations activities' more transparent and open to public participation, also thanks to new communication strategies pointing to offer an increasing number of information.

In accounting practice, information contributes to financial governance and accounting results diffusion. Consequently, they seem to have a direct influence on public trust in accounting system; thus, the accounting-trust relationship roots on: These systems ability in trust creation just as partners trust abstract systems, trust ability to act as a control mechanism that leads to a decreased need for formal control systems, and finally as a precondition for inter-organizational accounting (Mouritsen \& Thrane, 2006). The recent reform of public accounting and the subsequent implementation of innovative policies and tools are mainly oriented to both improve the general transparency of the whole public sector, national and local government decision-making, and to ensure citizens about public accounting fairness. The present study points to offer some insights on the role and the influence that emerging tools and policies have on public accounting and on public trust in these activities. In particular, this research tries to answer the following research questions:

RQ1: Public accounting reform has influenced/stimulated the use of technologies or specific management systems?

RQ2: Public accounting communication has a direct influence on public trust in financial institution actions and policies?

The paper is divided in two main sections, the first one dedicated to the analysis of public sector reformation, the shift from NPM to post-NPM, the role of communication on relationship between accounting management and public trust. The second one dedicated to the analysis of a specific case study, based on the experience of the Italian municipality of Amalfi in terms of accounting management reform.

\section{Theoretical Background}

\section{Public Sector Reformation: The Rising of Post New Public Management}

In these days, public sector is still evolving, thanks to the spread of information and communication technologies (ICTs) that finally make citizens able to participate to the solution of many different social problems (Dunleavy et al., 2006). According to several scholars, the post-NPM is currently being formed (Lodge \& Gill, 2011) in order to offer a better response to public sector deficiencies (Alford \& Hughes, 2008). If NPM can be defined as a perspective aiming to assure to public sector and its organizations a better administration based on the main feature of the so-called managerialism, according to which public sector can be managed using the same principles of private one (Troisi, 2015); on the other hand, the post-NPM reforms "focus more on building a strong and unified sense of values, trust, value-based management, and collaboration; team building; involving participating organizations; and improving the training and self-development” (Christensen \& Lægreid, 2007, 
p. 1060). In particular, in 1990s, NPM ${ }^{1}$ tried to respond to public sector deficits through specific strategies, budget plans, and implementing accounting policies aiming to compare processes, costs, and activities.

In literature, the debate about NPM was quite lively; thus, some scholars considered public and private sector too different to be managed according to the same principles (Hood, 1991; Dunleavy, Margetts, Bastow, \& Tinkler, 2005). NPM reforms were considered as "hands-on professional management” (Hood, 1991, p. 13), mainly based on explicit performance standards, output controls, organizational disaggregation, competition and contractualization, private sector-style management practices, and a parsimonious use of financial resources (Hood, 1991). However, the deep fragmentation and complexity arising from NPM has interested over the years several researchers and politicians (Christensen \& Lægreid, 2011), who need for more coordination and a more efficient and effective approach to public policies and services. Therefore, we are still living the transition from those decades in which efficiency promotion and government minimizing has been considered a general panacea to main shortcoming of public sector to an emerging and somewhat not well defined reform of this sector. This reformation has been alternatively defined as new state, good governance, neo-Weberian state or even developmental state (see Table 1).

All those definitions seem to be based on some common feature "especially emphasizing the rule of law, reliability, openness and transparency; accountability and responsibility; participation and effectiveness" (De Vries \& Nemec, 2013, p. 7). In this context, the so-called post-NPM reforms are mainly inter-organizationally oriented, pointing not only to a horizontal coordination of public organizations, but also to enhance the coordination between public and private actors. These reforms root on the emergent need for the restoration of a "common ethic" and a "cohesive culture", in order to face the loyalty corrosion and the growing mistrust typical of NPM era (Norman, 1995). One of the main aims of post-NPM reforms is counteract the erosion of the so-called "publicness" of public services, typical of NPM and aiming to reduce the democratic accountability level that has lead to its erosion (Haque, 2001). Nowadays, a largely shared definition of post-NPM is as difficult to achieve as for the one of NPM, mainly because “(...) post-NPM reforms-which partly revived some neo-Weberian features—-have been blended with some NPM features” (Christensen \& Lægreid, 2007, p. 8). Therefore, the post-NPM reform mainly roots on the development of a vertical and horizontal specialization in NPM (Christensen \& Lægreid, 2007). In particular, the vertical one is based on the use of more central resources dedicated to coordination of subordinate institutions and levels. This coordination can be achieved using stronger instruments of central control. On the other hand, the horizontal dimension is mainly based on those cross-sectoral bodies, programs, or projects used to modify the "pillarization" of the central public administration (Pollitt, 2003).

The emergence of the post-NPM has been deeply influenced by the potential of ICTs and digital technologies; thus, according to some scholars, NPM "has essentially died in the water" (Dunleavy et al., 2005, p. 468), under the strong impact of those technologies at the roots of the so-called "digital era governance" (DEG), characterized by the reintegration, needs-based holistic structures, and the digitalization of administrative processes (Lodge \& Gill, 2011). The digitalization of public administration has been supported by the orientation

\footnotetext{
1 The rise of NPM cannot be attributed to a single factor, but it reflects the pressures place on public departments and governments at the time (Leishman, Cope, \& Starie, 1995). For example, NPM was more readily accepted in New Zealand and the United Kingdom when compared to the USA, and in particular within education, health and welfare services than within police forces and agencies. Moreover, a number of Western nations adopted just few selected features of NPM, while others embraced a managerial ethic without a complete introduction of NPM (Butterfield, Edwards, \& Woodall, 2004).
} 
to network-based processes aiming to generate public value in a collaborative and cooperative way (Alford \& Hughes, 2008). Collaborative public value creation has been also enforced by the recent Web 2.0 technologies, which offer tools and platform dedicated to the interaction, the cooperation, and information sharing between different actors. Moreover, the post-NPM is also focused on the strengthening of political and administrative centres, and on the reintegration or definition of a stronger control over several agencies and state-owned enterprises (Christensen \& Lægreid, 2007).

Table 1

Key Themes Across Three Administrative Reform Ages

\begin{tabular}{|c|c|c|c|}
\hline \multicolumn{4}{|l|}{ Reform "ages" } \\
\hline & $\begin{array}{l}\text { PPA (progressive public } \\
\text { administration) }\end{array}$ & NPM & Post-NPM \\
\hline \multirow[t]{2}{*}{$\begin{array}{l}\text { Public sector } \\
\text { Distinctiveness (group } \\
\text { dimension) }\end{array}$} & $\begin{array}{l}\text { Uniform/Inclusive public service } \\
\text { Loosely defined provision }\end{array}$ & $\begin{array}{l}\text { Unbundling } \\
\text { Contractualization/Marketization }\end{array}$ & $\begin{array}{l}\text { "Whole of government" } \\
\text { Return to mixed pattern of } \\
\text { in-house and marketized } \\
\text { services; delivery networks }\end{array}$ \\
\hline & $\begin{array}{l}\text { Public sector ethos/career } \\
\text { Policy skills }\end{array}$ & \begin{tabular}{|l} 
Private sector style \\
Hands-on management skills
\end{tabular} & \begin{tabular}{|l|} 
Client based/Holism \\
Boundary-spanning skills
\end{tabular} \\
\hline $\begin{array}{l}\text { Rules versus discretion } \\
\text { (grid dimension) }\end{array}$ & $\begin{array}{l}\text { Implicit/Explicit qualitative } \\
\text { performance standards } \\
\text { Procedural controls }\end{array}$ & $\begin{array}{l}\text { Explicit performance standards } \\
\text { Output/Outcome controls }\end{array}$ & $\begin{array}{l}\text { Joined-up targets } \\
\text { Procedural/Centralized control; } \\
\text { Impartiality/Ethics rules }\end{array}$ \\
\hline
\end{tabular}

Note. Source: adapted form Lodge and Gill (2011).

\section{Public Accounting Management and Public Trust}

The emergence of the post-NPM paradigm has also influenced a general rethinking of public service development, delivering, and management. To achieve a better administration of public institutions, the implementation of accounting management specific practices and tools seem to be necessary; thus, these practices can contribute to achieve an efficient public finances administration. In particular, accounting management points to the development of "a well-defined results-based contract, based on clearly defined, result-oriented performance, rather than on the process to be followed" (United States General Accounting Office, 1997, p. 18). Moreover, an accounting system can be defined as "a way of aggregating and summarizing large amounts of data to facilitate good decision making” (Thaler, 1999, p. 183); while a public accounting system has been defined as "useful tool to discover and correct any 'deviation' from the benchmark value" (Mussari, 2014, p. 300). In particular, an accounting management system is mainly oriented to "audit performance information originating from the contractor to ensure its accuracy" (Organisation for Economic Co-operation and Development [OECD], 1997, p. 3).

The traditional accounting management systems "may not generate useful reports for management decision making when there are significant government policy changes” (Sciulli \& Wise, 2004, p. 5). In a traditional context, accounting management can offer to politicians both power and responsibility, while public managers can just implement accounting policies under the strong supervision of them. The emergence of the post-NPM seems to have influenced a general reformation of these practices, aiming to restore a "general ethic" in public sector management, also thanks to a stronger control over public administration actions and in particular on financial ones. In current public, accounting practices is often still difficult to estimate services' costs; thus, public agencies should renovate their accounting system in order to strive for socially efficient solutions and mediate between the interests of different social groups. This means that public accounting management should 
be oriented to external legitimacy maintenance, which refers to those processes aiming to justify accounting professional existence among different social actors, such as the state, public and private institutions, and even general public (Richardson, 1987).

In the post-NPM, trust is considered as a fundamental element of public sector reform, which is oriented to a general reinterpretation of modern government and the idea that public services can be entrusted "to expert providers who contract with the state to exercise management of resources in the public domain” (Budd, 2007, p. 540). Moreover, post-NPM reforms are mainly focused on a strong sense of value, trust, value-based management, and collaboration between public professionals and civil society (Christensen \& Lægreid, 2007). In particular, collaboration seems to have a deep influence on public trust development or improvement. In literature, trust has been defined as those expectations that involve a general moral order and specific competence and responsibility norms (Barber, 1983); while, according to Luhmann, it begins where knowledge ends, making people able to deal with an uncertain, complex, and threatening future (1979). Therefore, trust includes both those social and constitutive expectations characteristic of a specific institutional field (Simmel, 1964; Zucker, 1986). Social expectations refer to practices that are taken for granted and accepted by the majority of society's participants. These practices have come to be accepted as the correct way of behaving in certain situations and therefore function as "social rules". Consequently, public trust is related to the prevention of the destabilization arising from expectations' disappointment, which is generally common but without a formal, while according to Hollingsworth and White, it mainly roots on audit and proxy accountability, as well as fiduciary duty (1999). The general reform of public sector, involving also accounting system, cannot avoid to better investigate the relationship between these activities and public trust. Thus, it can be also enforced by the emergence of new system of public accounting management, mainly based on collaborative, open, and clear actions. In this context, trust between public and private parties seems to respond to a general needs for accounting controls (English and Baxter, 2010), based on a relationship between political, institutional, and civil parties, who share information about different activities.

\section{Accounting Public Policies and Tools: An Italian Overview}

In several countries, accounting systems and financial information have recently deteriorated and, in some cases, completely collapsed. However, their renovation still represents a concrete opportunity "for strengthened public expenditure management”; thus, the spread of new public accounting practices has been also influenced by general institutional reforms and modification, pointing to the introduction of costing, budgeting, and performance measurement tools (Jackson \& Lapsley, 2003). In the debates on post-bureaucracy, the role of technology on different aspects of public and private organizations management has involved also accounting practice and tools. In fact, the emergence of the post-NPM has led to the modernization and harmonization of public administration accounting system (Rossi \& Trequattrini, 2011). Therefore, public accounting "has shifted with new structures and management systems, there remains a lack of detailed knowledge of accounting practices themselves” (Jackson \& Lapsley, 2003, p. 361). In literature, accounting innovation has been read as directly related to the raising of wide communication networks, open to the participation and information sharing between public and private actors (Contini \& Lanzara, 2008). Consequently, a better access to information can positively affect the emergence of new relational networks involving different actors in public value creation (Daly, 2006). In this stream of research, several studies have considered that the implementation of emergent accounting technologies has able to offer interesting benefits in terms of organizational readiness, 
external pressures, changes in organizational strategy, structure, management systems and human capital skills, and openness to external sources of information (Spanos, Prastacos, \& Panlymenakon, 2002). In public sector, the adoption of specific tools dedicated to accounting management has been influenced by private sector solutions, such as Key Performance Indicators (KPIs), Balanced Score Card (BSC), Activity-Based Costing (ABC), Strategic Cost Management. In particular, the KPIs are currently used in private sector to develop an effective performance measurement system (PMS). This method offers a concrete support to decision-making, assisting managers in determining the more relevant indicators (Shahin \& Mahbod, 2007). In public sector, KPIs' adoption points to improve efficiency and effectiveness of government agencies in delivering public services. On the other hand, BSC has been designed to better understand the relationship among objectives, activities, and results, integrating them in the whole management process. This method contribute to an exact articulation of organisational objectives, strategy formulation, plans and budgets generation, and information system setting up in order to achieve a better performance monitoring and management (Smullen, 1997). BSC implementation points to offer a clear conception of vision, strategy, and outcomes in order to make public organizations able to succeed (Flak \& Dertz, 2005). Concluding, the ABC method is generally applied to a unified business process, in order to set the benchmark for processing, application, and claim costs. In particular, the ABC model generates performance statement which is sometimes identified as a "forth financial statement” in predictive accounting (Brimson, 2002).

This method allows cost-accountants to assign all overhead cost (those that cannot be apportioned directly to the products) to the activities that take place in an organization and then these activities with the help of activity-drivers are assigned to the products-services produced. The result is to have full information about the cost of products made. (Vazakidis, Karagiannis, \& Tsialta, 2010, p. 376)

In public sector reform, accounting practice plays a pivotal role; thus, 2009-2010 public accounting reform has been mainly based on public finance coordination and public accounting systems harmonization, supported by specific measures pointing to public spending transparency and control (Rossi \& Trequattrini, 2011). In Europe and in particular among EU (European Union) member states, this reform mainly roots not only on political and administrative decentralization, but also on the emergent need for an international coordination among the different government and also among the international bodies such as the United Nations and the European Union. Consequently, the specific measures pointing to address public accounting reform have been mainly based on laws financial sustainability, accounting systems' harmonization, and public finance control systems redesign (Rossi \& Trequattrini, 2011). This reform points to change the budget planning cycle in term of missions and spending programs, also through the definition of quantitative and measurable indicators, able to enforce the monitoring of public administration accounting practice.

In Italy, a general rethinking of public accounting was stimulated by 77/1995 decree, which made the accrual accounting compulsory for all local governments. A few years later, in 1997, also the budgetary process was reorganized; thus, each administrative departments had to draft its global budgets and link resource allocation to specific targets (output budgeting) (Kuhlmann, 2010). The accounting structure of the Italian Regions was strictly financial and based on specific authorization process and cash basis methodology; while, Italian local governments were characterized by the implementation of specific financial accounting systems, supported by accrual methodology. However, Italian regional administrative cultures and the constellation of local actors have led to the emergence of important differences in accounting reform application (Magnier, 
2003); thus, the leading municipalities in introducing such innovation were settled in North Eastern regions, Emilia-Romagna, Toscana, and Umbria (Lippi, 2001), while in other areas, and in particular in meridional ones, there was a substantial resistance to this innovative approach. Consequently, the adoption of emergent budgetary tools was initially limited to local level (Ongaro \& Valotti, 2008), where governments have "adopted planning and results assessment, budgeting financial autonomy for up to $60 \%$ of their resources, and diversified managerial strategies for their public services as far back as 1993” (Lippi, 2003, p. 152). It has also to be noted that until 2003, the 93\% of Italian municipalities had implemented an independent unit dedicated to managerial accounting services, while just the $50 \%$ of them had adopted innovative accounting methods (Capano, 2003). In terms of accounting reform, in 2005, the city of Pisa was the first local government to consolidate its financial accounts, thanks to the implementation of technical tools designed for a deeper monitoring of financial performances and a better management of achieved results (Kuhlmann, 2010). Consequently, Tuscany regional government chose this municipality to test its accounting reforms.

In Italy, the financial reform and in particular the modernization of public accounting system was not completely implemented as demonstrated by the rare inclusion in fiscal final reports of information about outputs or outcomes (Ongaro \& Valotti, 2008). This situation has been also detected by national survey conducted in 1999, according to which no more than one-quarter of national municipalities have defined performance indicators for financial efficiency and effectiveness measuring (Promberger \& Marteau, 2013). Concluding, the new accounting tools have somewhat obliged local public managers "to look at real processes instead of simply paper shuffling, to measure performance and output instead of hiding behind conformity to regulations" (Bobbio, 2005, p. 42).

\section{Methodology and Case Study Structure}

This paper has been based on a qualitative approach and in particular on the case study methodology (Yin, 2003; Fayolle, 2004) in order to better understands the real impact of emergent accounting tools on public finance, also through the experience of an Italian local municipality: Amalfi. The case study methodology is generally considered "a research strategy focused on the comprehension of those dynamics characteristic of specific contexts” (Eisenhardt, 1989, p. 532); thus, this approach facilitates the investigation of a phenomenon within its context, collecting data from several and sometimes-different sources, and making also possible to respond to specific research questions mainly through qualitative methods and action researches. The case study has been based on the analysis of Amalfi municipality in terms of new accounting systems implementation. The research has been conducted retrieving information both from primary and secondary sources (e.g., corporate web site, social media, blogs, corporate communication, etc.) and also through a semi-structured interview submitted to chief accountant of Amalfi municipality.

The case study analysis has been conducted examining the strategies and tools implemented by the municipality of Amalfi, a city settled in the south of Italy in Salerno County, which lies on Gulf of Salerno at the mouth of a deep ravine, surrounded by dramatic cliffs and coastal scenery. The semi-structured interview has gathered detailed information about this municipality approach to accounting management and its disposition to the appliance of new accounting policies and tools. The interview has been based on some key themes identified from literature review (accounting tools and policies; decision-making; communication), expressed through 15 questions. The interview lasted for about 30 minutes and it has been tape-recorded, transcribed verbatim, and analyzed according to a specific template; in order to cover each themes defined 
according to literature review results. The template has been coded in a matrix form, in order to record the action and disposition of Amalfi municipality in terms of accounting innovation, policies, and tools.

\section{Discussion}

This section is dedicated to a deep investigation of the influence of recent policies and tools dedicated to public accounting, according to the perspective and the experience of Amalfi municipality. The selected case study offers some evidences about the influence of emerging accounting policies and integrated management systems on public decision-making.

\section{Accounting Tools and Policies}

In terms of accounting tools and policies, the chief accountant has stated that, in line with the national general reformation of these activities, Amalfi municipality is used to apply the following methods: The cash flow statement and the management control, according to which results, the municipality has to compile specific document and format, in order to communicate these results to the central administrative institutions. The chief account has also stated that this sector and its activities has been recently restored, according to the main principles of harmonized accounting, even if in the last decade, a documental management system and other technological tools have been implemented.

We are used to compile every single document and format required by law, even if compiling them is not so simple, and mainly because of based on a rigid and unchangeable format.

Our sector has been recently rethought according to the main principles of harmonized accounting. However, the effects of this reform cannot be analyzed because it has been applied for the first time just in January in order to harmonize Italian accounting practice with European one, orienting our budget to cash management.

Our administration use from a long time informative tools and solutions dedicated to accounting data. We cannot imagine an efficient accounting management system without the concrete support of automated management systems.

\section{Decision-Making}

According to chief account, the reform of accounting policies has contributed both to enhance financial planning and reporting, and to achieve a better decision-making, which can be directly influenced by financial results.

The results of accounting practice have a direct effect on public decision-making, influencing not only financial, fiscal, and administrative activities, but also political ones.

\section{Communication}

In terms of communication, the interviewed manager has stated that its administration follows the legislative indication in terms of transparency, publishing on corporate website information about financial and fiscal activities three times a week. Public and private partners can access to these data directly through the corporate web site or making a formal request to access documents. Moreover, the communication of accounting activities is mainly based on corporate web site and traditional press organization.

Italian law has obliged all public administration to a transparent communication and information. We attend to this prescription publishing three times a week on corporate web site financial and fiscal information or data.

The institutional web site represents the most used channel through which our institution is used to communicate its accounting policies and the related results. However, we use also traditional press organization such as local journal, magazines, newspapers, and even local TV. 
Our communication strategies aim to make financial and fiscal organization information and data as transparent as possible. This means that our organization is always focused on possible or required improvement. Consequently, we are now starting to consider social media as a new and powerful communication channel also for accounting activities.

We consider communication and in particular financial/accounting communication fundamental to achieve a stronger and growing civil trust. In fact, trust can be feed also through the spread of clear and accessible information, directly provided by public institutions.

\section{Conclusions}

In the last decades, public accounting has passed through profound changes, pointing not only to the development of a specific regulation, but also to a general harmonization of public administration with international accounting model. In line with the reform promoted by the raising of post-NPM, public accounting has rethought its activities to improve value sharing, public trust, and collaboration. This emerging trend has been also observed in the Amalfi case study; thus, this institution is particularly sensitive to recent public accounting reforms, having implemented the main innovative policies and tools to achieve better financial results able to positively affect public decision-making and the relationship with local citizens.

The results achieved through literature review and the case study analysis have contributed to respond to first research question (Public accounting reform has influenced/stimulated the use of technologies or specific management systems?); thus, as stated before, the reform of public accounting is mainly oriented to a general disclosure to public opinion, which can be achieved also through the implementation of private sector accounting and managerial principles and techniques to the public one. This means that public administration to make this reform effective has to put into practice this specific policies and tools, in order to respond to national and international regulation and achieve a better management of fiscal and financial activities. The Amalfi case study has also showed that the reform of public accounting is a process not yet concluded, because it is still missing in terms of information monitoring. Consequently, little attention has been devoted, up to now, to questions concerning the true and fair view of the economic, financial and patrimonial situation of each reporting.

The investigation of public accounting influence on public trust and the case study results allowed us to respond also to second research question (Public accounting communication have a direct influence on public trust in financial institution actions and policies?); thus, both the more general post-NPM reform and the accounting reform are also focused on the restoring of a common ethic and cohesive culture in public sector, in order to make citizens able to participate in their actions and finally trust their results. In Italy, since from 2005 (Law 15/2005) public administrations have to communicate in a transparent way, in order to make citizens able to access all information they need. This prescription has been enforced the Article 10 of 69/2009 law, which states encourage participation, impartiality, and transparency to each administrative process or activity. Therefore, just in recent time to respect the previous legal requirements public administrations have started to publish online information about their activities, also about accounting ones, mainly on their institutional web site. It is evident that online communication gives a great contribution to public administration transparency, offering an increasing amount of information about its activities and polices, also when they are related to essential activities such as public accounting management. According to literature review results, trust between public and private parties can be also enforced by the definition of specific informative flows that can be accessed also from online communication channel by different social actors. This is true also for the communication of accounting activities results, because if well published and communicated (e.g., through online channels) can 
positively affect public trust and commitment. In terms of policies implications, a better and more extensive use of accounting systems and tools seems to be necessary to make Italian institutions able to respond not only to national and international legal requirements, but also to social demand for a transparent and open communication of financial and fiscal activities. The paper is somewhat limited by the research context, being focused on the analysis of just one Italian municipality settled in the south of Italy. Consequently, further research will be dedicated to better understand national approach to public accounting reform implementation and communication.

\section{References}

Alford, J., \& Hughes, O. (2008). Public value pragmatism as the next phase of public management. The American Review of Public Administration, 38, 130-148.

Barber, B. (1983). The logic and limits of trust. New Jersey: Rutgers University Press.

Bobbio, L. (2005). La democrazia deliberativa nella pratica (Deliberative democracy in practice). Stato e Mercato, 25(1), 67-88.

Brimson, J. A. (2002). The handbook of process-based accounting: Leveraging processes to predict results. AICPA.

Budd, L. (2007). Post-bureaucracy and reanimating public governance: A discourse and practice of continuity? International Journal of Public Sector Management, 20(6), 531-547.

Butterfield, R., Edwards, C., \& Woodall, J. (2004). The new public management and the UK police service: The role of the police sergeant in the implementation of performance management. Public Management Review, 6(3), 395-415.

Capano, G. (2003). Administrative traditions and policy change: When policy paradigms matter. The case of Italian administrative reform during the 1990s. Public Administration, 81(4), 781-801.

Christensen, T., \& Lægreid, P. (2007). The whole-of-government approach to public sector reform. Public Administration Review, 67(6), 1059-1066.

Christensen, T., \& Lægreid, P. (2011). Complexity and hybrid public administration-Theoretical and empirical challenges. Public Organization Review, 11(4), 407-423.

Contini, F., \& Lanzara, G. F. (2008). ICT and innovation in the public sector: European studies in the making of e-government. New York: Palgrave Macmillan.

Daly, H. E. (2006). Sustainable development—Definitions, principles, policies. The future of sustainability (pp. 39-53). Amsterdam: Springer Netherlands.

De Vries, M., \& Nemec, J. (2013). Public sector reform: An overview of recent literature and research on NPM and alternative paths. International Journal of Public Sector Management, 26(1), 4-16.

Dong, L., Christensen, T., \& Painter, M. (2009). A case study of China's administrative reform: The importation of the super-department. The American Review of Public Administration, 40(2), 170-188.

Dunleavy, P., Margetts, H., Bastow, S., \& Tinkler, J. (2005). New public management is dead—Long live digital-era governance. Journal of Public Administration Research and Theory, 16, 467-494.

Dunlevy, P., Burren, K. A., Mills, K., Chitty, L. S., Copp, A. J., \& Greene, N. D. (2006). Integrity of the methylation cycle is essential for mammalian neural tube closure. Birth Defects Research Part A: Clinical and Molecular Teratology, 76(7), 544-552.

Eisenhardt, K. M. (1989). Building theories from case study research. Academy of Management Review, 14(4), 532-550.

English, L., \& Baxter, J. (2010). The changing nature of contracting and trust in public-private partnerships: The case of Victorian PPP Prisons. Abacus, 46(3), 289-319.

Fayolle, A. (2004). French perspectives of international entrepreneurship. In L. Dana (Ed.), Handbook of research on international entrepreneurship (pp. 431-454). Cheltenham: Edward Elgar.

Flak, L. S., \& Dertz, W. (2005). Stakeholder theory and balanced scorecard to improve IS strategy development in public sector. Proceedings from the 28th Seminar on Information Systems Research in Scandinavia, Kristiansand, Norway. August.

Haque, M. S. (2001). The diminishing publicness of public service under the current mode of governance. Public Administration Review, 61(1), 65-82.

Hood, C. (1991). A public management for all seasons. Public Administration, 69(1), 3-19.

Jackson, A., \& Lapsley, I. (2003). The diffusion of accounting practices in the new “managerial” public sector. International Journal of Public Sector Management, 16(5), 359-372. 
Kuhlmann, S. (2010). New public management for the "Classical Continental European Administration”: Modernization at the local level in Germany, France and Italy. Public Administration, 88(4), 1116-1130.

Leishman, F., Cope, S., \& Starie, P. (1995). Reforming the police in Britain: New public management, policy networks and a tough “old bill”. International Journal of Public Sector Management, 8(4), 26-37.

Lippi, A. (2003). As a voluntary choice or as a legal obligation: Assessing new public management policy in Italy. In H. Wollmann (Ed.), Evaluation in public sector reform. Concepts and practice in international perspective (pp. 140-168). Cheltenham: Edward Elgar.

Lippi, F. (2001). Labor markets and monetary union: A strategic analysis. The Economic Journal, 111, 541-561.

Lodge, M., \& Gill, D. (2011). Toward a new era of administrative reform? The myth of post-NPM in New Zealand. Governance, 24(1), 141-166.

Luhmann, N., \& Schorr, K. E. (1979). Reflexionsprobleme im Erziehungssystem (Reflection problems in the education system) (Vol. 740). Stuttgart: Klett-Cotta.

Magnier, A. (2003). Subsidiarity: Fall or premise of "local government reforms". The Italian case. Reforming Local Government in Europe (Urban and Regional Research International), 4, 183-196.

Mouritsen, J., \& Thrane, S. (2006). Accounting, network complementarities and the development of inter-organisational relations. Accounting, Organizations and Society, 31(3), 241-275.

Mussari, R. (2014). EPSAS and the unification of public sector accounting across Europe. Accounting, Economics and Law, 4(3), 299-312.

Norman, R. (1995). New Zealand's reinvented government: Experiences of public managers. Public Sector, 18(2), 22-25.

Ongaro, E., \& Valotti, G. (2008). Public management reform in Italy: Explaining the implementation gap. International Journal of Public Sector Management, 21(2), 174-204.

Organisation for Economic Co-operation and Development (OECD). (1997). Best practice guidelines for contracting out government services. OECD.

Pollitt, C. (2003). The essential public manager. UK: McGraw-Hill Education.

Pollitt, C., \& Bouckaert, G. (2004). Public management reform: A comparative analysis. Oxford: Oxford University Press.

Promberger, M., \& Marteau, T. M. (2013). When do financial incentives reduce intrinsic motivation? Comparing behaviors studied in psychological and economic literatures. Health Psychology, 32(9), 950.

Richardson, A. J. (1987). Accounting as a legitimating institution. Accounting, Organizations and Society, 12(4), 341-355.

Rossi, N., \& Trequattrini, R. (2011). IPSAS and accounting systems in the Italian public administrations: Expected changes and implementation scenarios. Journal of Modern Accounting and Auditing, 7(2), 134-147.

Sciulli, N., \& Wise, V. (2004). Public sector market testing for contracting out: Some implications for accounting and management. Victoria University Occasional Papers, 5. Retrieved from http://vuir.vu.edu.au/214/1/op5.pdf

Shahin, A., \& Mahbod, M. A. (2007). Prioritization of key performance indicators: An integration of analytical hierarchy process and goal setting. International Journal of Productivity and Performance Management, 56(3), 226-240.

Simmel, G. (1964). The sociology of Georg Simmel. New York: Free Press.

Smullen, J. (1997). Balanced scorecards and activity-based management: The practical application. London: Pitman Publishing.

Spanos, Y., Prastacos, G., \& Panlymenakon, A. (2002). The relationship between information and communication technologies adoption and management. Information and Management, 39(8), 659-675.

Thaler, R. H. (1999). Mental accounting matters. Journal of Behavioral Decision Making, 12(3), 183-206.

Troisi, O. (2015). Governance e co-creazione di valore nella P.A. Una rilettura in otica Service-Dominant Logic (Governance and co-creation of value in public administration are reading in Service-Dominant Logic). Giappichelli, Torino.

United States General Accounting Office. (1997). Financial management: Outsourcing of finance and accounting functions. Report to Congressional Requesters, GAO/AIMD/NSIAD—98-43, October, United States General Accounting Office, Washington, DC.

Vazakidis, A., Karagiannis, I., \& Tsialta, A. (2010). Activity-based costing in the public sector. Journal of Social Sciences, 6(3), 376-382.

Yin, R. K. (2003). Case study research: Design and methods (3rd ed.). Thousand Oaks, CA: Sage.

Zucker, L. G. (1986). Production of trust: Institutional sources of economic structure, 1840-1920. Working Paper Series, No. 82. 